\title{
Building the first step: a review of low-intensity interventions for stepped care
}

\author{
John McKellar ${ }^{1 *}$, Julia Austin ${ }^{2}$ and Rudolf Moos ${ }^{1}$
}

\begin{abstract}
Within the last 30 years, a substantial number of interventions for alcohol use disorders (AUDs) have received empirical support. Nevertheless, fewer than $25 \%$ of individuals with alcohol-related problems access these interventions. If several intensive psychosocial treatments are relatively effective, but most individuals in need do not access them, it seems logical to place a priority on developing more engaging interventions. Accordingly, after briefly describing findings about barriers to help-seeking, we focus on identifying an array of innovative and effective low-intensity intervention strategies, including telephone, computer-based, and Internet-based interventions, that surmount these barriers and are suitable for use within a stepped-care model. We conclude that these interventions attract individuals who would otherwise not seek help, that they can benefit individuals who misuse alcohol and those with more severe AUDs, and that they can facilitate subsequent help-seeking when needed. We note that these types of low-intensity interventions are flexible and can be tailored to address many of the perceived barriers that hinder individuals with alcohol misuse or AUDs from obtaining timely help. We also describe key areas of further research, such as identifying the mechanisms that underlie stepped-care interventions and finding out how to structure these interventions to best initiate a program of stepped care.
\end{abstract}

Keywords: Alcohol use disorders, Stepped care, Help seeking, Intervention

\section{Introduction}

Within the last 30 years, a number of psychosocial interventions for alcohol use disorders (AUDs) have received empirical support. Evaluations of these interventions have employed well-controlled randomized trials involving large numbers of individuals and substantial followup periods. These trials provide strong support for such interventions as motivational enhancement, cognitivebehavioral treatment, and 12-step facilitation treatment [1]. In addition, it is now clear that individuals who obtain timely help for AUDs have better outcomes than those who do not $[2,3]$.

Despite these advances, only about $25 \%$ of individuals with AUDs access any form of help, empirically supported or otherwise [4-7]. When help is sought, it often occurs 10 or more years after the onset of symptoms of disorder [8]. If several intensive psychosocial treatments are relatively effective, but most individuals in need do

\footnotetext{
* Correspondence: John.McKellar@va.gov

${ }^{1}$ Center for Healthcare Evaluation, Health Services Research and Development Service, Department of Veterans Affairs Health Care System and Stanford University School of Medicine, Palo Alto, CA, USA Full list of author information is available at the end of the article
}

not access them, it seems logical to place a priority on developing more engaging interventions. Accordingly, after briefly describing findings about barriers to helpseeking, we focus on identifying a palatable array of innovative and effective low-intensity intervention strategies that surmount these barriers and are suitable for use within a stepped-care model.

\section{Key barriers to help-seeking}

Empirical studies of help-seeking over the last two decades highlight a number of reasons why individuals with AUDs delay or never seek treatment. One key set of factors involves individuals' perceptions of negative concomitants of treatment, including stigma $[9,10]$, dislike of the prevalent group format and the emphasis on spirituality in treatment and self-help groups [10], lack of privacy [10], concern that treatment is ineffective [11], and disinterest in abstinence goals [10,12].

Other common reasons individuals cite for not entering treatment involve a desire for autonomy or a wish to "handle problems more on their own" $[9,11,12]$ and the belief that their alcohol problems are not serious or may 
improve on their own $[10,12,13]$. Factors such as the need for childcare [14], the problem of arranging transportation or traveling long distances to care $[15,16]$, and the cost of treatment and lack of adequate insurance coverage also hinder help-seeking [17]. Finally, the time commitment for standard alcohol treatment is high, ranging from nine hours a week for intensive outpatient care to full-time for residential care. Many individuals report a lack of willingness to dedicate such substantial amounts of time to treatment and to accept the resulting interference with responsibilities to family or work [10].

\section{Stepped-care models}

Stepped-care models [18] provide one important method for capitalizing on the appealing qualities of lowintensity interventions, such as their accessibility and autonomy, while providing the opportunity to refer individuals to more intensive treatment when needed. The development of low-intensity initial entrees into treatment is consistent with naturalistic studies of the help-seeking process, which show that individuals often engage in self-quit attempts prior to entering formal or informal treatment [19-21]. Lack of success in a lowintensity intervention could further heighten individuals' perceptions of the severity of their drinking problems and spur interest in treatment entry, which is readily available within a stepped-care program.

\section{Low-intensity interventions}

A number of low-intensity interventions are suitable for use as a first step of a stepped-care intervention. We focus here on low-intensity interventions that do not require face-to-face interaction. Although there is considerable support for the effectiveness of screening and brief intervention (SBI) in nonspecialty settings such as primary care [22,23], widespread implementation remains elusive. Some of the reasons for low levels of implementation in these settings include lack of training, lack of clinician time, and inadequate reimbursement [24], and the widespread reluctance of providers who are not addiction specialists to talk with patients about alcohol use [25].

We examine three main questions about the suitability of these interventions as candidates for stepped interventions. First, do low-intensity interventions attract individuals who would otherwise not seek help? Second, do individuals who are engaged in heavy alcohol use benefit from these interventions and, importantly, can individuals with moderately or relatively severe AUDs benefit from them? We categorize samples as "moderately to relatively severe" if they include patients diagnosed with alcohol dependence or if their average scores on the Alcohol Use Disorders Identification Test (AUDIT) are >19 and in the range of likely alcohol dependence [26]. Finally, does engagement in a lowintensity intervention inspire subsequent help-seeking when needed? We operationalize "inspiring subsequent help-seeking" as studies where patients seek treatment in the year following the low-intensity intervention. We summarize the evidence presented by these studies, examine their limitations, and discuss issues related to implementation of stepped-care models.

\section{Methods}

\section{Search procedure}

We considered for inclusion peer-reviewed Englishlanguage articles that examined alcohol interventions delivered via bibliotherapy, telephone (including Short Message Service [SMS]), computer, or the Internet. Both original articles and meta-analyses were deemed suitable. Our review was performed using the electronic databases of the US National Library of Medicine (PubMed) and the American Psychological Association (PsycInfo) to identify relevant articles published from 1990 through September 2011. The term "alcohol" was combined with the following search terms: web-based intervention, Internet intervention, online intervention, bibliotherapy, text message, book intervention, telephone intervention, remote intervention, computer intervention, and selfhelp intervention (excluding Alcoholics Anonymous [AA] or 12-step). The term "intervention" was added to most search terms to identify the most relevant articles. In addition to searching electronic databases, we examined potentially relevant articles cited in the identified articles' reference section [27].

\section{Results}

Using these procedures, we identified a total of 686 articles via PubMed and an additional 382 articles via PsycInfo (1068 unique articles). The titles of all identified articles were examined for correspondence with the study inclusion criteria. This led to the identification of 77 articles of potential interest for further review. The content of these 77 articles was carefully examined by two reviewers who further excluded studies that had the following characteristics: provision of face-toface care, an insufficient follow-up rate to evaluate the intervention including failure to account for missing data, participant age $<18$, college samples (which are less representative of clinical samples [28]), or use of highly specialized clinical samples (e.g., a trial targeting pregnant women to decrease incidence of fetal alcohol syndrome). The reviewers identified 18 that met study inclusion and exclusion criteria. These articles are described below in the text and are summarized in Table 1. 
Table 1 Summary of included studies: salient characteristics and outcomes

\begin{tabular}{|c|c|c|c|c|c|c|c|c|}
\hline $\begin{array}{l}\text { Intervention } \\
\text { modality }\end{array}$ & Investigators & Study design & Sample & Elements of intervention & $\begin{array}{l}\text { Magnitude of alcohol } \\
\text { consumption change \& } \\
\text { dependence measure }\end{array}$ & $\begin{array}{l}\text { Attract } \\
\text { individuals* }\end{array}$ & $\begin{array}{l}\text { Positive } \\
\text { outcomes** }\end{array}$ & $\begin{array}{l}\text { Inspire } \\
\text { help- } \\
\text { seeking } \dagger\end{array}$ \\
\hline \multirow[t]{2}{*}{ Bibliotherapy } & \multirow[t]{2}{*}{$\begin{array}{l}\text { Apodaca \& } \\
\text { Miller (2003) }\end{array}$} & \multirow[t]{2}{*}{$\begin{array}{l}\text { Meta-analytic review of } \\
22 \text { bibliotherapy studies }\end{array}$} & \multirow[t]{2}{*}{$\begin{array}{l}\text { Included studies broadly } \\
\text { targeting "problem } \\
\text { drinkers" }\end{array}$} & \multirow[t]{2}{*}{$\begin{array}{l}\text { Included studies invited } \\
\text { participants to read and } \\
\text { implement self-help materials }\end{array}$} & $\begin{array}{l}\text { Bibliotherapy versus control } \\
\text { (self-referred drinkers), } \\
d=0.31\end{array}$ & \multirow[t]{2}{*}{$x$} & \multirow[t]{2}{*}{$X X$} & \multirow[t]{2}{*}{$x$} \\
\hline & & & & & $\begin{array}{l}\text { Dependence measure: } \\
\text { varied across studies (e.g., } \\
\text { abstinence rates, alcohol } \\
\text { consumption frequency, } \\
\text { liver enzyme levels) }\end{array}$ & & & \\
\hline \multirow[t]{3}{*}{ Bibliotherapy } & \multirow{3}{*}{$\begin{array}{l}\text { Sobell et al } \\
\text { (2002) }\end{array}$} & Randomized trial & \multirow{3}{*}{$\begin{array}{l}\text { Individuals who consumed } \\
->12 \text { drinks per week or } \geq 5 \\
\text { drinks on } \geq 5 \text { days in the } \\
\text { year prior to assessment }\end{array}$} & \multirow{3}{*}{$\begin{array}{l}\text { Participants received } 1 \text { of } 2 \\
\text { written interventions by mail: 1) } \\
\text { Motivational enhancement-based } \\
\text { feedback and advice } \\
\text { (personalized based on } \\
\text { participants' drinking history and } \\
\text { patterns); } 2 \text { ) General information } \\
\text { on the effects of alcohol, } \\
\text { guidelines for safe use, and } \\
\text { information on self -monitoring }\end{array}$} & \multirow{3}{*}{$\begin{array}{l}\text { No significant differences } \\
\text { between groups in alcohol } \\
\text { consumption change }\end{array}$} & \multirow[t]{3}{*}{$x$} & \multirow[t]{3}{*}{$X X$} & \multirow[t]{3}{*}{$x$} \\
\hline & & $\begin{array}{l}\text { Motivational } \\
\text { enhancement/ } \\
\text { personalized } \\
\text { feedback }(n=414) ;\end{array}$ & & & & & & \\
\hline & & $\begin{array}{l}\text { Bibliotherapy/drinking } \\
\text { guidelines }(n=411)\end{array}$ & & & & & & \\
\hline \multirow[t]{3}{*}{ Bibliotherapy } & \multirow{3}{*}{$\begin{array}{l}\text { Cunningham } \\
\text { et al (2002) }\end{array}$} & Randomized trial & \multirow{3}{*}{$\begin{array}{l}\text { Individuals who expressed } \\
\text {-interest in self-help and } \\
\text { scored } \geq 8 \text { on the AUDIT }\end{array}$} & \multirow{3}{*}{$\begin{array}{l}\text { Drink Wise, which uses CBT } \\
\text { principles, served as the self-help } \\
\text { text. Personalized assessment/ } \\
\text { feedback was based on the } \\
\text { "Drinker's Check-up" and included } \\
\text { personalized assessment, } \\
\text { normative feedback, and } \\
\text { information regarding the } \\
\text { potential negative consequences } \\
\text { of alcohol use }\end{array}$} & \multirow{2}{*}{$\begin{array}{l}\text { Self-help book \& } \\
\text { personalized assessment/ } \\
\text { feedback versus single } \\
\text { treatment or control, } \\
\mathrm{d}=0.21\end{array}$} & & \multirow[t]{3}{*}{$x$} & \\
\hline & & \multirow{2}{*}{$\begin{array}{l}\text { Self-help book }(n=22) ; \\
\text { personalized assessment/ } \\
\text { feedback }(n=21) ; \text { self-help } \\
\text { book \& personalized } \\
\text { assessment/feedback } \\
(n=17) ; \text { no materials } \\
(n=26)\end{array}$} & & & & & & \\
\hline & & & & & $\begin{array}{l}\text { Dependence measure: } \\
\text { Mean days per week of } \geq 5 \\
\text { drinks per occasion during } \\
\text { a typical week in the } \\
\text { 6-month follow-up period }\end{array}$ & & & \\
\hline \multirow[t]{3}{*}{ Bibliotherapy } & \multirow{3}{*}{$\begin{array}{l}\text { Bamford et al } \\
(2005)\end{array}$} & Randomized trial & \multirow{3}{*}{$\begin{array}{l}\text { Individuals presenting for } \\
\text {-clinic-based alcohol } \\
\text { treatment }\end{array}$} & \multirow{3}{*}{$\begin{array}{l}\text { Participants received a 6-page } \\
\text { leaflet based on FRAMES }\end{array}$} & Leaflet versus no leaflet, & & \multirow[t]{3}{*}{$x$} & \multirow[t]{3}{*}{$x$} \\
\hline & & \multirow{2}{*}{$\begin{array}{l}\text { Leaflet condition } \\
(\mathrm{n}=180) \text {; } \\
\text { no leaflet condition } \\
(\mathrm{n}=181)\end{array}$} & & & $d=0.20$ & & & \\
\hline & & & & & $\begin{array}{l}\text { Dependence measure: } \\
\text { Self-rated categorical } \\
\text { (yes/no) reduction in } \\
\text { alcohol use at follow-up }\end{array}$ & & & \\
\hline \multirow[t]{2}{*}{ Bibliotherapy } & \multirow{2}{*}{$\begin{array}{l}\text { Wild et al } \\
\text { (2007) }\end{array}$} & Randomized trial & \multirow[b]{2}{*}{$\begin{array}{l}\text { Current drinkers (used } \\
\text {-alcohol in the } 12 \text { months } \\
\text { prior to assessment) with no } \\
\text { previous participation in } \\
\text { alcohol treatment who had } \\
\text { an interest in self-help } \\
\text { materials }\end{array}$} & \multirow[b]{2}{*}{$\begin{array}{l}\text { The self-help pamphlet gave } \\
\text { normative feedback regarding } \\
\text { drinking habits and included } \\
\text { information on the hazards of } \\
\text { alcohol use at various } \\
\text { consumption levels, guidelines for } \\
\text { reducing alcohol use, and referral } \\
\text { to a local treatment hotline }\end{array}$} & \multirow[t]{2}{*}{ Unable to calculate } & & \multirow[t]{2}{*}{$x$} & \\
\hline & & $\begin{array}{l}\text { Pamphlet }(n=877) \text {; } \\
\text { no pamphlet }(n=850)\end{array}$ & & & & & & \\
\hline
\end{tabular}


Table 1 Summary of included studies: salient characteristics and outcomes (Continued)

\begin{tabular}{|c|c|c|c|c|c|c|c|}
\hline \multirow[t]{2}{*}{ Bibliotherapy } & \multirow{2}{*}{$\begin{array}{l}\text { Kavanagh \& } \\
\text { Connolly } \\
\text { (2009) }\end{array}$} & Randomized trial & \multirow{2}{*}{$\begin{array}{l}\text { Individuals who met DSM-IV } \\
\text { "criteria for an AUD }\end{array}$} & \multirow[b]{2}{*}{$\begin{array}{l}\text { Participants were enrolled in } \\
\text { primary care and received } \\
\text { information regarding the effects } \\
\text { of alcohol, self-monitoring forms, } \\
\text { and a self-help booklet. The } \\
\text { mailed correspondence treatment } \\
\text { further included personalized } \\
\text { progress letters and } 8 \text { CBT-based } \\
\text { newsletters }\end{array}$} & \multirow{2}{*}{$\begin{array}{l}\text { Dependence measure: } \\
\text { Mean drinks per } \\
\text { week }=0.39\end{array}$} & \multirow[t]{2}{*}{$X X$} & \\
\hline & & $\begin{array}{l}\text { Immediate mailed } \\
\text { intervention }(n=103) \text {; } \\
\text { delayed mailed } \\
\text { intervention }(n=101)\end{array}$ & & & & & \\
\hline \multirow{4}{*}{$\begin{array}{l}\text { Telephone- } \\
\text { delivered } \\
\text { intervention }\end{array}$} & \multirow{4}{*}{$\begin{array}{l}\text { Brown et al } \\
\text { (2007) }\end{array}$} & Randomized trial & \multirow{4}{*}{$\begin{array}{l}\text { Individuals who met DSM-IV } \\
\text {-criteria for alcohol abuse or } \\
\text { dependence who were } \\
\text { drawn from primary care }\end{array}$} & \multirow{4}{*}{$\begin{array}{l}\text { The telephone-based intervention } \\
\text { consisted of } 6 \text { sessions based on } \\
\text { Ml principles and the stages of } \\
\text { change model. Behavioral } \\
\text { techniques were used to monitor } \\
\text { sobriety goals. Participants were } \\
\text { also sent individualized letters } \\
\text { summarizing progress after } \\
\text { sessions }\end{array}$} & \multirow{2}{*}{$\begin{array}{l}\text { Telephone-based } \\
\text { intervention versus control } \\
\text { (male participants) =0.16 }\end{array}$} & \multirow[t]{4}{*}{$X X$} & \\
\hline & & $\begin{array}{l}\text { Telephone-based } \\
\text { intervention }(n=445) \text { : }\end{array}$ & & & & & \\
\hline & & control $(n=452)$ & & & $\begin{array}{l}\text { The intervention was not } \\
\text { superior to control for } \\
\text { women }\end{array}$ & & \\
\hline & & & & & $\begin{array}{l}\text { Dependence measure: } \\
\text { Total standard drinks } \\
\text { consumed in the month } \\
\text { prior to 3-month follow-up } \\
\text { interview }\end{array}$ & & \\
\hline \multirow{2}{*}{$\begin{array}{l}\text { Telephone- } \\
\text { delivered } \\
\text { intervention }\end{array}$} & \multirow{2}{*}{$\begin{array}{l}\text { Mello et al } \\
\text { (2008) }\end{array}$} & Randomized trial & \multirow{2}{*}{$\begin{array}{l}\text { Noncritically injured } \\
\text {-emergency department } \\
\text { patients who used alcohol } \\
\text { at risky levels per NIAAA } \\
\text { quantity/frequency } \\
\text { guidelines }\end{array}$} & \multirow{2}{*}{$\begin{array}{l}\text { Targeted individuals with a recent } \\
\text { alcohol-related injury. Counselors } \\
\text { initiated } 2 \text { brief calls ( } 30 \text { minutes } \\
\& 15 \text { minutes) based on } \mathrm{Ml} \\
\text { principles }\end{array}$} & \multirow{2}{*}{$\begin{array}{l}\text { No significant differences } \\
\text { between groups in alcohol } \\
\text { consumption change }\end{array}$} & \multirow[t]{2}{*}{$x$} & \\
\hline & & $\begin{array}{l}\text { Telephone-based } \\
\text { intervention }(n=140) \text {; } \\
\text { control }(n=145)\end{array}$ & & & & & \\
\hline \multirow{3}{*}{$\begin{array}{l}\text { Computer- } \\
\text { based } \\
\text { intervention }\end{array}$} & \multirow{3}{*}{$\begin{array}{l}\text { Hester et al } \\
(2005)\end{array}$} & Randomized trial & \multirow{3}{*}{$\begin{array}{l}\text { Individuals who scored } \geq 8 \\
\text {-on the AUDIT }\end{array}$} & \multirow{3}{*}{$\begin{array}{l}\text { Participants were given access to } \\
\text { computer-based Ml. Components } \\
\text { include assessment and } \\
\text { normative feedback, decisional } \\
\text { balance, and negotiating sobriety } \\
\text { goals }\end{array}$} & \multirow{2}{*}{$\begin{array}{l}\text { Pre versus post for } \\
\text { computer-based } \\
\text { intervention, }=1.05\end{array}$} & \multirow[t]{3}{*}{$x$} & $x$ \\
\hline & & $\begin{array}{l}\text { Computer-based } \\
\text { intervention }(n=35) \text { : }\end{array}$ & & & & & \\
\hline & & control $(n=26)$ & & & $\begin{array}{l}\text { Dependence measure: } \\
\text { Mean of } 3 \text { dependent } \\
\text { variables (average drinks } \\
\text { per day, drinks per drinking } \\
\text { day, and average peak BAC } \\
\text { level) during 12-month } \\
\text { follow-up period }\end{array}$ & & \\
\hline \multirow{3}{*}{$\begin{array}{l}\text { Computer- } \\
\text { based } \\
\text { intervention }\end{array}$} & \multirow{3}{*}{$\begin{array}{l}\text { Neumann } \\
\text { et al (2006) }\end{array}$} & Randomized trial & \multirow{3}{*}{$\begin{array}{l}\text { Emergency department } \\
\text {-patients who scored } \geq 5 \text { on } \\
\text { the AUDIT }\end{array}$} & \multirow{3}{*}{$\begin{array}{l}\text { Patients in the active treatment } \\
\text { condition were given access to } \\
\text { computer-delivered personalized } \\
\text { advice and normative feedback. } \\
\text { Feedback was based on the Ml } \\
\text { principles and FRAMES guidelines. } \\
\text { Other components included } \\
\text { information about alcohol and } \\
\text { provider referral information }\end{array}$} & \multirow{2}{*}{$\begin{array}{l}\text { Computer-based } \\
\text { intervention versus } \\
\text { control }=0.20\end{array}$} & \multirow[t]{3}{*}{$x$} & \\
\hline & & Computer-based & & & & & \\
\hline & & control $(n=575)$ & & & $\begin{array}{l}\text { Dependence measure: } \\
\text { Proportion of participants } \\
\text { who met British Medical } \\
\text { Association criteria for } \\
\text { at-risk drinking at } 6 \text { months } \\
\text { post-treatment }\end{array}$ & & \\
\hline
\end{tabular}


Table 1 Summary of included studies: salient characteristics and outcomes (Continued)

\begin{tabular}{|c|c|c|c|c|c|c|c|}
\hline \multirow{2}{*}{$\begin{array}{l}\text { Computer- } \\
\text { based } \\
\text { intervention }\end{array}$} & \multirow[t]{2}{*}{$\begin{array}{l}\text { Boon et al } \\
\text { (2011) }\end{array}$} & \multirow{2}{*}{$\begin{array}{l}\text { Randomized trial } \\
\text { Computer-based advice } \\
(n=230) ; \text { control } \\
(n=220)\end{array}$} & \multirow{2}{*}{$\begin{array}{l}\text { Drinkers with alcohol } \\
\text {-consumption levels } \\
\text { exceeding the limits set by } \\
\text { the Dutch guidelines for } \\
\text { low-risk drinking }\end{array}$} & \multirow{2}{*}{$\begin{array}{l}\text { Participants in the treatment } \\
\text { group received normative } \\
\text { feedback and information } \\
\text { regarding the negative } \\
\text { consequences of alcohol use. } \\
\text { Personalized advice was informed } \\
\text { by participant drinking patterns, } \\
\text { self-efficacy and attitude, and } \\
\text { stage of change }\end{array}$} & $\begin{array}{l}\text { Intervention versus } \\
\text { control }=0.25\end{array}$ & & \multirow[t]{2}{*}{$x$} \\
\hline & & & & & $\begin{array}{l}\text { Dependence measure: } \\
\text { Meeting or failing to meet } \\
\text { Dutch guidelines for } \\
\text { low-risk drinking at } \\
\text { 1-month follow-up }\end{array}$ & & \\
\hline \multirow{3}{*}{$\begin{array}{l}\text { Internet- } \\
\text { based } \\
\text { intervention }\end{array}$} & \multirow{3}{*}{$\begin{array}{l}\text { Cunningham } \\
\text { et al (2009) }\end{array}$} & Randomized trial & \multirow{3}{*}{$\begin{array}{l}\text { Drinkers who scored } \geq 4 \text { on } \\
\text { the } 3 \text { consumption items } \\
\text { on the AUDIT-C \& expressed } \\
\text { an interest in self-help }\end{array}$} & \multirow{3}{*}{$\begin{array}{l}\text { Participants in the active } \\
\text { condition were mailed a URL that } \\
\text { allowed them to access the } \\
\text { screening program, which } \\
\text { provided a personalized } \\
\text { assessment and normative } \\
\text { feedback }\end{array}$} & \multirow{2}{*}{$\begin{array}{l}\text { Mailed intervention URL } \\
\text { versus control, } \eta_{p}^{2}=0.08\end{array}$} & & \multirow[t]{3}{*}{$x$} \\
\hline & & \multirow{2}{*}{$\begin{array}{l}\text { Sent URL by mail to } \\
\text { participate in intervention } \\
(n=92) ; \text { control }(n=93)\end{array}$} & & & & & \\
\hline & & & & & $\begin{array}{l}\text { Dependence measure: Mean } \\
\text { drinks consumed per week } \\
\text { during follow-up period }\end{array}$ & & \\
\hline \multirow{4}{*}{$\begin{array}{l}\text { Internet- } \\
\text { based } \\
\text { intervention }\end{array}$} & \multirow{4}{*}{$\begin{array}{l}\text { Pemberton } \\
\text { et al (2011) }\end{array}$} & Quasi-randomized trial & \multirow{4}{*}{$\begin{array}{l}\text { Active duty military } \\
\text {-personnel }\end{array}$} & \multirow{4}{*}{$\begin{array}{l}\text { Participants assigned to active } \\
\text { treatment received either AS or } \\
\text { DCU. Controls received no } \\
\text { intervention. Both interventions } \\
\text { were adapted for a military } \\
\text { population via expert consensus }\end{array}$} & \multirow{2}{*}{$\begin{array}{l}\text { AS versus control = no } \\
\text { significant differences in } \\
\text { alcohol consumption } \\
\text { change }\end{array}$} & & \multirow[t]{4}{*}{$x$} \\
\hline & & \multirow{3}{*}{$\begin{array}{l}\text { Internet-based intervention } \\
\text { based on social learning } \\
\text { theory (AS) }(n=686) ; \\
\text { Internet-based intervention } \\
\text { based on Ml principles } \\
(D C U)(n=1470) \text {; control } \\
(n=914)\end{array}$} & & & & & \\
\hline & & & & & $\overline{D C U}$ versus control $=0.10$ & & \\
\hline & & & & & $\begin{array}{l}\text { Dependence measure: } \\
\text { Average drinks per drinking } \\
\text { occasion during 1-month } \\
\text { follow-up }\end{array}$ & & \\
\hline \multirow{3}{*}{$\begin{array}{l}\text { Internet-based } \\
\text { intervention }\end{array}$} & \multirow{3}{*}{$\begin{array}{l}\text { Riper et al } \\
\text { (2007) }\end{array}$} & Randomized trial & \multirow{3}{*}{$\begin{array}{l}\text { Drinkers whose } \\
\text { consumption levels } \\
\text { exceeded Dutch guidelines } \\
\text { for low-risk drinking }\end{array}$} & \multirow{3}{*}{$\begin{array}{l}\text { Online self-help protocol was } \\
\text { consistent with CBT and self- } \\
\text { control principles. The } \\
\text { intervention was accessed via the } \\
\text { study website and included goal } \\
\text { setting and analysis of alcohol } \\
\text { behavior. Participants also had } \\
\text { access to a peer-to-peer chat } \\
\text { room }\end{array}$} & \multirow{2}{*}{$\begin{array}{l}\text { Online self-help versus } \\
\text { control }=0.40\end{array}$} & \multirow[t]{3}{*}{$x$} & \multirow[t]{3}{*}{$x$} \\
\hline & & \multirow{2}{*}{$\begin{array}{l}\text { Online self-help, }(n=130) \\
\text { control }(n=131)\end{array}$} & & & & & \\
\hline & & & & & $\begin{array}{l}\text { Dependence measure: } \\
\text { Mean weekly alcohol } \\
\text { consumption during } \\
\text { 6-month follow-up period }\end{array}$ & & \\
\hline \multirow{3}{*}{$\begin{array}{l}\text { Internet-based } \\
\text { intervention }\end{array}$} & \multirow{3}{*}{$\begin{array}{l}\text { Postel et al } \\
\text { (2010) }\end{array}$} & Pre-post design & \multirow{3}{*}{$\begin{array}{l}\text { Individuals concerned } \\
\text {-about their drinking }\end{array}$} & \multirow{3}{*}{$\begin{array}{l}\text { Therapy was delivered online by } \\
\text { a therapist who communicated } \\
\text { with the patient asynchronously. } \\
\text { Treatment was a blend of CBT } \\
\text { and motivational enhancement, } \\
\text { along with elements from the } \\
\text { stages-of-change model. Therapy } \\
\text { assignments were given in } 2 \\
\text { stages; patients could choose } \\
\text { (with therapist approval) to } \\
\text { move to the second stage of } \\
\text { treatment }\end{array}$} & \multirow{2}{*}{$\begin{array}{l}\text { Pre- versus post- } \\
\text { intervention }=1.11\end{array}$} & \multirow[t]{3}{*}{$x$} & \multirow[t]{3}{*}{$x x$} \\
\hline & & \multirow{2}{*}{$\overline{(\mathrm{N}=527)}$} & & & & & \\
\hline & & & & & $\begin{array}{l}\text { Dependence measure: } \\
\text { Mean weekly alcohol } \\
\text { consumption immediately } \\
\text { post-treatment }\end{array}$ & & \\
\hline
\end{tabular}


Table 1 Summary of included studies: salient characteristics and outcomes (Continued)

\begin{tabular}{|c|c|c|c|c|c|c|}
\hline \multirow{5}{*}{$\begin{array}{l}\text { Internet-based } \\
\text { intervention }\end{array}$} & \multirow{5}{*}{$\begin{array}{l}\text { Blankers et al } \\
\text { (2011) }\end{array}$} & \multirow{5}{*}{$\begin{array}{l}\text { Randomized trial } \\
\text { Internet-based self-help, } \\
(\mathrm{SAO})(\mathrm{n}=68) ; \text { Internet- } \\
\text { based therapy (TAO) } \\
(n=68) ; \text { control (WL) } \\
(n=69)\end{array}$} & \multirow{5}{*}{$\begin{array}{l}\text { Score }>8 \text { on the AUDIT and } \\
\text { consumption of }>14 \\
\text { standard drinks in a week }\end{array}$} & \multirow{4}{*}{$\begin{array}{l}\text { SAO: An automated, fully self- } \\
\text { guided Internet intervention } \\
\text { based on elements of MI } \\
\text { and CBT. } \\
\text { TAO: A therapist-led online } \\
\text { intervention (elaborated version } \\
\text { of SAO's MI/CBT protocol plus } 7 \\
\text { synchronous chat-based therapy } \\
\text { sessions) }\end{array}$} & \multirow{5}{*}{$\begin{array}{l}\text { TAO versus } W L=0.59 \mathrm{SAO} \\
\text { versus } \mathrm{WL}=0.36 \\
\text { Dependence measure: } \\
\text { Number of drinks in the } \\
7 \text { days prior to 3-month } \\
\text { follow-up }\end{array}$} & \multirow[t]{5}{*}{$x X$} \\
\hline & & & & & & \\
\hline & & & & & & \\
\hline & & & & & & \\
\hline & & & & Control: waitlist (WL) condition & & \\
\hline \multirow{2}{*}{$\begin{array}{l}\text { Internet-based } \\
\text { intervention }\end{array}$} & \multirow{2}{*}{$\begin{array}{l}\text { Wallace et al } \\
\text { (2011) }\end{array}$} & Randomized trial & \multirow{2}{*}{$\begin{array}{l}\text { Individuals who accessed } \\
\text { the DYD website and } \\
\text { scored } \geq 5 \text { on the AUDIT-C }\end{array}$} & \multirow{2}{*}{$\begin{array}{l}\text { Participants in the active condition } \\
\text { received access to the DYD } \\
\text { interactive online alcohol } \\
\text { intervention based on CBT, MI, and } \\
\text { relapse prevention techniques }\end{array}$} & \multirow{2}{*}{$\begin{array}{l}\text { DYD versus control = no } \\
\text { significant differences in } \\
\text { alcohol consumption } \\
\text { change }\end{array}$} & \multirow[t]{2}{*}{$x$} \\
\hline & & $\begin{array}{l}\text { "Down Your Drink" } \\
\text { Internet-based } \\
\text { intervention (DYD) } \\
\mathrm{n}=3972) ; \text { control } \\
(\mathrm{n}=3963)\end{array}$ & & & & \\
\hline \multirow{3}{*}{$\begin{array}{l}\text { Internet-based } \\
\text { intervention } \\
\text { (television- } \\
\text { supported) }\end{array}$} & \multirow{3}{*}{$\begin{array}{l}\text { Kramer et al } \\
\text { (2009) }\end{array}$} & Randomized trial & \multirow{3}{*}{$\begin{array}{l}\text { Drinkers whose } \\
\text {-consumption levels } \\
\text { exceeded Dutch guidelines } \\
\text { for low-risk drinking }\end{array}$} & \multirow{3}{*}{$\begin{array}{l}\text { Participants in active treatment } \\
\text { were asked to use a CBT-based, } \\
\text { television-supported online self- } \\
\text { help intervention. The } 5 \text {-part series } \\
\text { depicts a coach guiding } 2 \\
\text { individuals with alcohol problems } \\
\text { through an intervention. } \\
\text { Participants also received written } \\
\text { self-help materials and access to } \\
\text { the website }\end{array}$} & \multirow{2}{*}{$\begin{array}{l}\text { Television-based } \\
\text { intervention versus } \\
\text { control = } 0.90\end{array}$} & \multirow[t]{3}{*}{$x$} \\
\hline & & $\begin{array}{l}\text { Television-supported } \\
\text { intervention }(n=90) \text {. }\end{array}$ & & & & \\
\hline & & control $(n=91)$ & & & $\begin{array}{l}\text { Dependence measure: } \\
\text { Mean weekly alcohol } \\
\text { consumption at follow-up }\end{array}$ & \\
\hline
\end{tabular}
the website

*Attract Individuals = X indicates the intervention appeared to attract individuals who might otherwise not seek help (defined as those who had not previously sought treatment or who expressed disinterest in formal treatment).

**Positive Outcomes $=\mathrm{X}$ indicates the intervention significantly reduced alcohol use; XX indicates the intervention significantly reduced alcohol use in more severe drinkers (alcohol dependence diagnosis or AUDIT >19). tlnspire help-seeking $=X$ indicates the intervention appeared to be associated with future help-seeking.

Abbreviations: MI motivational interviewing, CBT cognitive-behavioral therapy, AUDIT Alcohol Use Disorders Identification Test, NIAAA National Institute on Alcohol Abuse and Alcoholism.

Note: For 4 of the studies, Cohen's was calculated by the authors using the Effect Size Determination Program (Lipsey \& Wilson, 1996) based on either given study chi-square statistics (Bamford et al., 2005; Boon et al., 2011); alcohol consumption outcome summary statistics (Brown et al., 2007); or by comparing the proportion of participants in each condition who no longer met criteria for at-risk drinking as defined by that study (Neumann et al., 2006). Apodaca and Miller (2003) limited effect size calculations to bibliotherapy studies where patients received $\leq 1$ meeting with a clinician. The Cohen's calculation for Bamford et al. (2005) was based on participants' reduction in alcohol use. The Cohen's calculation for Brown et al. (2007) compared alcohol consumption at 3-month follow-up for the experimental group versus control (as opposed to change from baseline). Although the Mello et al. (2008) treatment was not associated with a change in alcohol consumption, impaired driving scores did improve with controls (= 0.31). Pemberton et al. (2011) was designated as quasi-randomized because assignment to active treatment was only available at select study sites. The Cohen's calculation for Postel et al. (2010) only included participants who completed the treatment (Parts 1 \& 2). 


\section{Study effect-size determination}

Effect sizes presented (Cohen's d or $\eta_{\mathrm{p}}^{2}$ ) were obtained directly from the original study calculations in all but four cases [29-32]. Calculations for these four studies were derived from available study statistics using the Effect Size Determination Program from the Toolkit for Practical Meta-Analysis [33].

\section{Bibliotherapy interventions}

Bibliotherapy is the provision of written self-help materials to motivate or guide the process of changing drinking behavior. Bibliotherapy may be presented in the form of brief information and education such as in a pamphlet or in the form of a self-guided book or workbook. A meta-analysis by Apodaca and Miller [34] evaluated the effectiveness of a range of bibliotherapeutic interventions. These interventions involved self-guided learning of behavioral and cognitive-behavioral skills aimed at achieving either abstinence or reduction in drinking to nonhazardous levels. Interventions included components such as monitoring alcohol intake, identifying triggers of alcohol use, and setting drinking goals. The vast majority of self-referred participants were recruited via media outlets, and many indicated disinterest in formal treatment options, indicating that the intervention attracted individuals who had not previously sought help.

Compared with control conditions, self-referred individuals who participated in bibliotherapy tended to improve more on problem drinking. Further, there were no significant differences between bibliotherapy and more extensive face-to-face interventions for self-referred individuals, even for interventions that offered up to 12 face-to-face sessions. The authors categorized participants in these studies as problem drinkers without severe dependence, suggesting that severity ranged from alcohol abuse to mild/moderate alcohol dependence. A number of studies noted that individuals who had previously not entered formal treatment or mutual-help groups did so after participating in bibliotherapy. However, it is not possible to establish definitively the effects of bibliotherapy on help-seeking, as the studies did not report subsequent help seeking separately for intervention and control conditions. Studies involving participants who were opportunistically screened (e.g., who were identified by random digit dialing) yielded more heterogeneous outcomes, only some of which tended to support the use of bibliotherapy.

Sobell and colleagues [35] used media outlets (newspapers, television, radio) to recruit participants who had never sought formal treatment and mailed them two versions of an intervention. Participants reported average consumption of $>12$ drinks per week or consuming five or more drinks on five or more occasions and average AUDIT scores of 20 (low range of alcohol dependence). Individuals in this study were randomized to a self-change condition that included personalized feedback on drinking or to a control condition (receipt of educational materials focused on safe levels of drinking and consequences of harmful drinking). The selfchange condition provided personalized feedback describing drinking levels relative to other drinkers, high-risk situations, and motivation to change, and the bibliotherapy version contained information about the effects of alcohol, low-risk drinking guidelines, risky drinking conditions, and drinking logs. No differences were found by intervention type (self-change versus bibliotherapy) at one-year follow-up; individuals in both groups reduced total weekly drinking by an average of $28.3 \%(\mathrm{p}<0.001)$ and reduced heavy/binge-drinking days by $33 \%$ ( $<<0.001)$. Moreover, almost $25 \%$ of participants in both the self-change and the control conditions had sought treatment. Thus, the current study cannot specify that personalized feedback inspired subsequent helpseeking, but the provision of bibliotherapy and repeated assessments present in both conditions may have led participants to seek help in the subsequent year after entering the study.

Cunningham and colleagues [36] assessed the effectiveness of a self-help book and a personalized assessment-feedback intervention both separately and in combination with each other in a general population study. Individuals with AUDIT scores of $\geq 8$ ( 86 in total) were recruited via use of random-digit dialing and then randomized into conditions including no treatment, selfhelp book, personalized feedback, or both self-help book and personalized feedback. The self-help book called Drink Wise: How to Quit Drinking or Cut Down [37] was chosen based on demonstrated success in prior evaluations [38]. At six-month follow-up, participants randomized to the book and feedback condition achieved better drinking outcomes compared with those randomized to just one of the interventions or to no treatment at all. Specifically, interaction analyses comparing those in the combined group to those in the singleintervention groups report significantly fewer drinks per week $(\mathrm{F}=5.4,1 / 75 \mathrm{df}, \mathrm{p}<0.03$; effect size, 0.07) and days per week of five or more drinks per drinking day $(\mathrm{F}=19.6,1 / 75 \mathrm{df}, \mathrm{p}<0.001$; effect size, 0.21$)$. This study is one of the few to find a synergistic effect of using feedback in conjunction with self-help materials.

A study by Bamford and colleagues [29] examined the effect of a six-page preparatory leaflet mailed to participants $(\mathrm{N}=361)$ prior to entering treatment. The study randomized individuals scheduled to enter specialty alcohol treatment to an intervention condition that received the preparatory pamphlet or to a no-pamphlet control group. The preparatory leaflet was based on the 
FRAMES acronym (Feedback, Responsibility, Advice, Menu of options, Empathy, and Self-efficacy) with a goal of motivating individuals to begin the drinking change process prior to initiating treatment. Rates of treatment entry were $10 \%$ higher for the leaflet than the no-leaflet group, although the effect was not statistically significant $(x=3.61, p=0.057)$. This study is the only one included in this review to specifically investigate the impact of a low-intensity intervention on treatment entry.

Wild and colleagues [39] studied six-month outcomes in a sample of current drinkers $(\mathrm{N}=1722)$ randomly assigned to either brief personalized feedback on drinking norms or delayed-treatment. The brief personalized feedback intervention, presented as a mailed pamphlet, invited drinkers to compare their alcohol consumption with that of men or women in the general population. Although there was no main effect of experimental condition on drinks per drinking day for the entire sample, individuals who drank hazardous amounts $(>14$ drinks per week for men or $>9$ for women) improved more than those who drank less heavily; that is, the hazardous drinking $\times$ intervention effect was significant $(B=-0.124, t=$ $2.5, \mathrm{p}<0.01)$. Thus, the intervention impacted individuals who were drinking in a hazardous fashion more than those who were nonhazardous drinkers.

Kavanagh and Connolly [40] evaluated the impact of a mail intervention on 204 men and women with an alcohol use disorder (abuse or dependence). The intervention was a single-blind randomized trial with a cross-over design wherein participants receiving the intervention either immediately or delayed by three months. The intervention was cognitive behavioral in nature and involved motivation enhancement, challenging overly positive alcohol expectancies, specifying drink refusal skills, and maintaining nonalcohol-related social support. The intervention was divided into eight components delivered weekly for the first month and biweekly thereafter. Compared with participants in the delayed condition, those in the active condition had a more significant reduction in alcohol consumption (Wald $x^{2}(1)=7.46, p=0.006$ ). Participants cut their drinking almost in half but continued to drink at fairly high levels, with men reporting 27 drinks per week and women 14 drinks per week. Even so, the reduction in drinking is notable given that the average AUDIT score at intake was 22.3, indicating moderate alcohol dependence.

\section{Telephone interventions}

Telephone interventions increase accessibility of care by eliminating the need for travel to a treatment center [41]. We identified two telephone studies that met inclusion criteria. One study randomized primary-care patients who screened positive for an AUD (alcohol abuse or dependence) to receive either a brief telephone motivational interviewing (MI) intervention (up to six sessions) or a four-page pamphlet on healthy lifestyles [31]. At three-month follow-up, men in the telephone condition experienced greater reductions in risky drinking days (30\%) than men in the pamphlet (8\%) condition ( $\mathrm{n}=201, \mathrm{p}<0.001)$; women experienced significant reductions in drinking in both the telephone (17\%) and pamphlet (12\%) conditions $(\mathrm{n}=251$; not significant). Participants who met diagnostic criteria for alcohol dependence improved as much as those who only met criteria for alcohol abuse.

A second telephone study [42] randomized emergencydepartment patients within five days of admission to a two-session telephone intervention or standard care (assessment only). Participants included individuals who screened positive for hazardous alcohol use ( $\geq 14$ drinks per week for men or $\geq 7$ for women, or $\geq 5$ drinks per occasion for men or $\geq 4$ per occasion for women). Both groups improved in drinking outcomes at three-month follow-up, but only the telephone group (mean change $=$ $-1.4 ; 95 \% \mathrm{CI},-3.0$ to 0.2 ) reported significantly reduced impaired driving compared with the standard-care group (mean change $=1.0 ; 95 \% \mathrm{CI},-0.9$ to 2.9$)(\mathrm{p}=0.04)$. Similar to results of the bibliotherapy studies [36,39], individuals reporting heavier drinking experienced the most benefit from the telephone intervention.

\section{Computer-based interventions}

The benefits of computer-based interventions include the potential for remote access, the ability for individuals to choose content they prefer, and increased appeal of multimedia applications. Hester and coworkers [43] evaluated the "Drinker's Check-up," a brief computerbased MI intervention that includes assessment, personalized feedback, and a decision-making module that takes about 45-60 minutes to complete. Individuals were solicited by media announcements and needed to be drinking in a problematic fashion as indicated by an AUDIT score $>8$ (the mean AUDIT score was 20 for all participants). Subjects were randomized to the intervention or a four-week waitlist (control condition). At one-month follow-up, individuals randomized to the intervention condition reported significantly lower levels of drinking from baseline to eight weeks $(F(6,43)=2.667$; $\mathrm{p}=0.027)$. At one-year follow-up, both the intervention and delayed intervention groups reported a $50 \%$ decline in quantity and frequency of drinking, indicating strong support for the intervention. At 12-month follow-up, it was also found that 28 of the 61 participants subsequently engaged in formal treatment or had attended AA. This help-seeking may have been inspired by content within the computer program, which included treatment referral information. These findings seem to 
support the apparent effectiveness of the intervention on subsequent help seeking, despite the lack of a nointervention control.

Another study [32] evaluated a brief (15-20 minute) computer-based MI intervention for emergencydepartment patients. The study randomized 1139 individuals with AUDIT scores $>5$ to intervention or control conditions. The intervention consisted of computergenerated feedback about current drinking delivered on the computer and in a letter provided to the participant prior to leaving the emergency department. In addition to feedback on safe-drinking norms, the letter provided a FRAMES-based intervention [44]. Participants began the study at similar levels of hazardous drinking; however, at six months, $21.7 \%$ of the intervention group versus $30.4 \%$ of the control group met criteria for hazardous drinking $(\mathrm{p}=0.008)$, and at 12 months, alcohol intake in the intervention group decreased by $22.8 \%$ compared with $10.9 \%$ in the control group $(\mathrm{p}=0.02)$.

A third study [30] evaluated a brief (20-minute) computer feedback intervention known as "DrinkTest" for men recruited from a nationally representative panel in the Netherlands. Participants met Dutch criteria for hazardous alcohol use ( $\geq 15$ drinks per week or $\geq 4$ on a single occasion at least once per week) and were randomized to the intervention or to a control group that received an educational pamphlet. The intervention provided normative feedback on drinking, enumerated potential consequences of heavy drinking, and provided suggestions for reducing alcohol intake. At one-month follow-up, the intervention produced significant benefits, with $42 \%$ of those in the experimental condition reporting drinking within recommended limits compared with $31 \%$ in the control condition $\left(x^{2}=6.67, p=0.01\right)$. At sixmonth follow-up, the intervention effects were less strong, with drinking within recommended limits reported by $46 \%$ and $37 \%$ of the intervention and control conditions, respectively $\left(x^{2}=3.25, p=0.07\right)$.

\section{Internet-based interventions}

The Internet offers another method for reaching individuals with AUDs. One form of Internet-based intervention involves assisting individuals in assessing and evaluating their own drinking. Cunningham and colleagues [45] tested the Internet-based "Check Your Drinking" intervention in a random sample of drinkers who met criteria for hazardous alcohol use (score of $\geq 4$ on the three-item AUDIT-C). Participants were randomly assigned to either the "Check Your Drinking" intervention, which provided brief personalized normative feedback (approximately 10 minutes), or to a no-feedback control condition. Individuals scoring $>11$ on the AUDIT-C were categorized as problem drinkers. Problem drinkers assigned to the feedback condition reported a significant reduction in drinking at three-month followup $(\mathrm{p}<0.05)$ and an additional reduction at six-month follow-up ( $\mathrm{p}<0.05)$, whereas problem drinkers in the control condition did not show significant reductions in drinking.

A study by Pemberton and colleagues [46] compared the effectiveness of two web-based alcohol interventions, "Alcohol Savvy" and "Drinker's Check-up," which were adapted for use within a military population. "Alcohol Savvy" is an alcohol-misuse prevention program that uses education about the risks of drinking and the benefits of moderate alcohol consumption to create motivation for individuals to make better decisions regarding alcohol use. The version of "Drinker's Check-up" used this study was an online version of the intervention described previously in the computer section (MI for high-risk drinkers). Study participants $(\mathrm{N}=3070)$ were active-duty military personnel who were voluntarily recruited through a variety of means at eight different installations. Participants did not need to meet any screening criteria for hazardous alcohol use. Randomization to either of the active conditions or a waitlist (control) condition was quasi-randomized; participants who lacked access to high-speed Internet were assigned to "Drinker's Check-up" as their active condition due to the technical requirements of the "Alcohol Savvy" intervention. At onemonth follow-up, participants who completed the "Drinker's Check-up" reported significant reductions in average number of drinks per occasion ( $p>0.05)$ compared with controls. The comparison between "Alcohol Savvy" and the control group was not significant.

Complex web-based alcohol treatment involves more elaborate forms of engagement beyond feedback interventions, such as communication between users, communication with clinical personnel, and/or content meant to be perused over weeks or months. The web-based "Drinking Less" intervention [47] includes interactive materials based on cognitive-behavioral and self-control principles and a moderated peer-to-peer discussion forum. In a study to assess its effectiveness, participants were block-randomized to either the intervention or a control condition involving a web-based psychoeducational brochure about the negative impacts of unhealthy alcohol use. Problem drinkers in the study included men who consumed $\geq 14$ drinks per week or $\geq 4$ drinks in one day, and women who consumed $\geq 10$ drinks per week or $\geq 3$ drinks in one day. Among individuals in the intervention condition, $17 \%$ decreased drinking to safe levels at six-month followup compared with only $5 \%$ in the control condition $(\mathrm{OR}=3.66$; CI 1.3-10.8; $\mathrm{p}=0.006)$. Individuals in the intervention condition also reported an average reduction of weekly drinking of 11 drinks at six-month follow-up, compared with the control group's reduction of only two drinks $(\mathrm{OR}=5.86$; $\mathrm{CI}, 5.86-18.10 ; \mathrm{p}=0.001)$. The vast 
majority (88\%) of users of the website had never entered professional treatment, indicating that interventions of this nature may appeal to problem drinkers uninterested in traditional alcohol-treatment services.

An e-therapy alcohol intervention [48] included assessment, goal-setting, and regular interaction with counselors via email for up to three months. Participants $(\mathrm{N}=156)$ who met the study's criterion for problem drinking ( $\geq 15$ drinks per week for men and $\geq 11$ for women) were recruited via online advertising and randomized to three months of access to the website or to a waitlist (control condition). The intervention was facilitated by email contact from a counselor and occurred in two stages: a motivational stage that involved assessment of drinking consequences and feedback and a second phase that involved completing modules based on cognitive behavioral therapy for alcohol problems. At three-month follow-up, participants randomized to the intervention reduced their weekly alcohol intake by a 26 drinks compared with those in the control group, who decreased weekly alcohol intake by only two drinks (mean difference 95\% CI, 15.69-35.80; $\mathrm{p}<0.001$ ). Almost $80 \%$ of participants met the Diagnostic and Statistical Manual of Mental Disorders, $4^{\text {th }}$ revision (DSM-IV) criteria for mild alcohol dependence, and 76\% reported never having received treatment for their alcohol problems.

Another intervention study of problem drinkers, conducted by Blankers and colleagues [49], evaluated the effectiveness of an Internet-based alcohol intervention (therapy alcohol online [TAO]), and Internet-based selfhelp (self-help alcohol online [SAO]). Participants scored $>8$ on the AUDIT (mean score for all participants, 19.5) and reported drinking $>14$ drinks per week on average. At total of 205 participants were randomized to TAO, $\mathrm{SAO}$, or a waitlist (control condition). The SAO condition was a stand alone, fully automated, self-guided intervention based on cognitive-behavioral therapy and MI techniques. Participants in the SAO group also received support from other SAO participants in the form of an Internet-based forum. The TAO condition was a synchronous online intervention based on the same SAO treatment protocol but also included 40minute text-based therapy chat sessions. Contact between TAO participants and participants could occur synchronously during chat sessions or asynchronously via email. At three-month follow-up, generalized regression models indicated significantly lower alcohol consumption for the TAO group $(\mathrm{p}=0.002)$ and the SAO group $(\mathrm{p}=0.03)$ relative to the waitlist group. From baseline to three-month follow-up, the TAO group reduced their weekly alcohol consumption by an average of 24 drinks compared with a reduction of 16 drinks in the SAO group and 12 in the waitlist group. The mean reduction in weekly drinking between the TAO and SAO groups was not significantly different at threemonth follow-up, but a significant difference favored the SAO group $(p=0.03)$ at six months.

A study of the "Down Your Drink" web-based intervention [50] compared an interactive website employing elements of MI with cognitive behavioral techniques with a more static, text-based version of the site that focused on harms caused by excessive alcohol consumption. Interactive components of the "Down Your Drink" website were divided into three stages focusing on individual responsibility for change, deciding on change, and maintenance of change, and included e-tools such as a "thinking drinking diary" in which users could record their alcohol consumption along with emotional and behavioral triggers. Hazardous drinkers who had AUDIT-C scores $>5(\mathrm{~N}=7935)$ were randomized to either the enhanced "Down Your Drink" website or to the textbased site (control condition). At three-month followup, the intervention group reported a substantial reduction in alcohol consumption (46.3 to 26.4 drinks per week) as did the control group (45.7 to 25.6), but the difference between groups was not significant (OR, 1.03; 95\% CI, 0.97-1.10.) Changes were maintained in both groups at 12 months.

The "Drinking Less" intervention described earlier was also tested via a television-supported platform [51]. Problem drinkers $(\mathrm{N}=181)$ were recruited using the "Drinking Less" website and assigned to receive weekly DVDs (five in total, 25 minutes each) and a self-help manual or to a waitlist (control condition). The content of the DVDs paralleled that of the "Drinking Less" website but also showed two problem drinkers who underwent and completed the intervention with a trained addiction coach. At five-week follow-up, $40 \%$ of individuals in the intervention condition were engaging in low-risk drinking compared with only $7 \%$ of individuals in the waitlist condition $\left(\mathrm{x}^{2}(1)=28.3 ; \mathrm{p}=0.001\right.$; $\mathrm{OR}, 9.4$; 95\% CI, 3.7-23.9). The reductions in drinking remained at three-month follow-up.

\section{Discussion}

A variety of low-intensity interventions can engage individuals and effectively reduce drinking. Moreover, these strategies offer easier access and flexibility to individuals who misuse alcohol and circumvent some of the barriers to entry into traditional treatment. They also offer the potential for greater privacy, although strong encryption and other safeguards are needed to ensure that individuals' data remain private and confidential for online interventions. In the following section, we summarize three key findings from existing studies of low-intensity interventions and identify three important areas for future research on stepped-care intervention models. 


\section{Key findings about low-intensity interventions}

Low-intensity interventions attract individuals who have not previously sought help. Several of the studies discussed herein included participants who had never sought treatment previously or who expressed disinterest in formal treatment options but accepted the lowintensity intervention. Mail [35], Internet-based [47,48], and bibliotherapeutic [34] interventions can attract individuals who have never previously sought treatment, including those who meet criteria for alcohol abuse or dependence [34,35]. None of the other studies reviewed above reported on participants' prior help-seeking history, so it is not possible to determine whether any one type of intervention is especially attractive to individuals with AUDs. Moreover, we are unaware of studies that have offered a low-intensity intervention or any treatment to individuals who report disinterest in formal or informal treatment options. More comparative information is needed about which low-intensity interventions are most attractive to individuals with AUDs who are unlikely to attend more traditional formal treatment. We also need to know whether some modalities are more popular than others for specific groups of individuals. In this vein, less educated individuals were more likely to be drawn to the "Drinking Less" intervention when it was delivered via television [51] than when it was delivered via the Internet [47]. Another important question for future studies is whether low-intensity interventions, offered in the context of a stepped-care intervention, are more likely to attract problem drinkers relative to offering more intensive treatment.

Low-intensity interventions can benefit individuals with more severe AUDs. Meta-analytic studies suggest that brief interventions conducted in settings such as primary care tend to be more effective for individuals with less severe AUDs [23]. Similar to face-to-face brief interventions, all of the low-intensity interventions reviewed herein significantly reduced alcohol use among participants. However, several of the studies also reported significantly reduced alcohol use among patients with low to moderate alcohol dependence. For example, Brown and colleagues [31] found that a telephone-based intervention produced equivalent outcomes for participants who met criteria for abuse or dependence. A bibliotherapeutic intervention reduced drinking among participants meeting criteria for alcohol abuse or dependence by 50\% [40], another bibliotherapy intervention reduced alcohol use by $30 \%$ [35], and two online interventions reduced drinking by $50 \%$ [47-49] — despite the fact that participants in these four studies reported average AUDIT scores of $>19$. Thus, low-intensity interventions appear to significantly reduce drinking among hazardous alcohol users and can also engage and reduce drinking among individuals with more severe alcohol-related problems.
Low-intensity interventions may lead to subsequent help-seeking. Low-intensity interventions may inspire a self-change attempt which, if unsuccessful, leads to subsequent help-seeking [35]. Almost half of the individuals who participated in the computer-based "Drinker's Check-up" sought some form of additional help within the next 12 months [43]. Almost one-quarter of the individuals in the mail-based intervention [35] sought some form of help for their alcohol use in the subsequent year, including "control" participants, potentially inspired by completion of study assessments. A number of studies reviewed by Apodaca and colleagues [34] indicated that individuals who had previously not entered formal treatment or mutual-help groups did so after participating in bibliotherapy. A majority of individuals who engaged in e-therapy indicated that they would consider seeking treatment, and some decided to participate in face-toface therapy [48]. Thus, consistent with prior findings showing that unsuccessful quit attempts often precede help-seeking [19-21], low-intensity interventions may help individuals engage in subsequent treatment even when the interventions themselves are unsuccessful at precipitating change. It is not possible to establish definitively the effects of these interventions on help-seeking, as participants in the intervention and control conditions either sought subsequent help at equal rates, subsequently received the same intervention, or results were not reported separately for the different groups.

Assessing subsequent help-seeking in the context and aftermath of low-intensity interventions could provide valuable data to inform stepped-care interventions. We need to know whether individuals seek help after a lowintensity intervention because they resumed problematic drinking (failed to meet goals) and/or whether lowintensity interventions help dispel concerns about treatment and thereby increase individuals' motivation to enter into it.

\section{Key questions for implementing stepped-care interventions}

How can low-intensity interventions be structured to initiate a stepped-care intervention? In general, lowintensity interventions appear well-suited as the first step of a stepped-care intervention $[35,47,48]$. However, a number of important questions need to be addressed regarding how best to integrate low-intensity interventions into standard treatment. For example, should individuals who participate in a low-intensity intervention but are unsuccessful at reducing their alcohol use be actively referred to more intensive treatment, or should they just be provided with referral information? Is it more appealing for a low-intensity intervention to be remotely accessible and independent than for it to be specifically tied to an alcohol treatment center? Stepped- 
care models are a potentially efficient method for titrating care for individuals with AUDs, but attention should also be directed to whether or not any given model successfully increases the reach of alcohol treatment.

Another potential implementation pathway for lowintensity interventions is as population-based interventions that focus more on the overall impact on groups of individuals than on efficacy for each individual. Within this framework, the "impact" of an intervention is not only its efficacy, such as a $5 \%$ decrease in hazardous alcohol use, but the efficacy multiplied by the number of participants [52]. The efficacy of online interventions such as "Drinking Less" in the Netherlands, which decreased the rate of hazardous alcohol consumption by $17 \%$, may appear modest compared with most treatment outcome studies that report abstinence rates of $30-40 \%$ [53]. However, with the ability to reach a large number of homes, the "Drinking Less" website could have a substantial population-based impact on drinking.

In countries such as the US, where higher intensity treatment options are widely available, a variety of lowintensity interventions can be included as part of population-based stepped intervention, as currently exists with "AlcoholScreening.org" [54]. Similarly, the computerbased "Drinker's Check Up" [43], which combined a lowintensity intervention with referral information, resulted in $45 \%$ of the participants seeking additional help. Combining low-intensity intervention with referral to intensive treatment in the US is feasible given the existence of online resources such as the Substance Abuse Treatment Facility Locator [55] and mutual-help meeting locators for groups such as AA [56], Smart Recovery [57], and Life Ring [58].

The success of smoking quitlines offers another model for population-based alcohol interventions [59]. Smoking quitlines have strong empirical support [60] and additional advantages such as convenience, relative anonymity, and ease of creating a structured counseling protocol. Lichtenstein and colleagues [59] identify problem drinking as well-suited to the quitline model, given that the disorder is highly prevalent, that suitable protocols for intervention currently exist, and that the widespread negative impacts of hazardous drinking provide governments with a stake in funding such an enterprise. Alcohol quitlines could follow problem drinkers long enough to determine the success or failure of the intervention, and then, per the stepped care model, offer referral to more intensive treatment to individuals who remain motivated to reduce their level of drinking.

What are the mechanisms that underlie the benefits of low-intensity interventions? Gaining a better understanding of how low-intensity interventions work, particularly within the process of seeking help, can inform the creation and implementation of stepped-care interventions. We know that alcohol-related problems, particularly multiple problems, predict help-seeking and reductions in drinking. All of the low-intensity interventions in this review provided online or telephone feedback about negative consequences associated with drinking [31,48], automated initial assessments [45], or self-help materials [43,47]. With one exception [35], all of the studies found better alcohol outcomes when personalized feedback and informational advice were provided than when they were not provided. However, to more fully understand the impact of personalized feedback on subsequent drinking, we need to examine the extent to which the feedback changes the perceived severity of alcohol problems or another potential mediator, and whether any such changes are tied to changes in drinking [61]. Support for such a causal chain could substantiate the effectiveness of personalized feedback and contribute to a better understanding of "why" or "how" low-intensity interventions work.

We also need to examine whether certain aspects of low-intensity interventions, such as feedback about negative consequences of drinking or providing information about normative drinking, are especially likely to lead to subsequent treatment seeking. Is an initial assessment and evaluation sufficient to motivate help-seeking, or is participation in the intervention and an unsuccessful quit attempt the key to help-seeking? Gaining a better understanding of how low-intensity interventions help individuals recognize the severity of their alcoholrelated problems offers the hope of telescoping the normal help-seeking process and thereby averting a considerable degree of alcohol-related harm.

Are some low-intensity interventions more beneficial for some groups (e.g., men or women) than others, and are there additional low-intensity interventions that should be considered? Design of stepped-care interventions should take into account the potential for lowintensity interventions to be more or less effective for some groups. More information is needed about the extent to which low-intensity interventions are effective across diverse population groups. As noted, Brown and colleagues [31] found that a telephone-based intervention was more effective than a pamphlet-only condition for men but not for women. More generally, there is a need to examine whether low-intensity treatment interventions are differentially effective across gender and sociodemographic and racial/ethnic groups. For example, less well-educated individuals were more likely to be drawn to the "Drinking Less" intervention when it was delivered via television [51] than when it was delivered via the Internet [47]. It may be appropriate to adopt theory-based, data-driven cultural adaptation techniques [62] to modify low-intensity interventions for 
different cultural groups. In addition, given that almost $20 \%$ of the US population speaks a language other than English [63], future research should develop and test low-intensity interventions for AUDs in languages other than English.

A recent report by the Pew Research Center's Internet and American Life Project [64] indicates that $83 \%$ of American adults own cell phones, and $73 \%$ send and receive text messages. Most studies evaluating the impact of text messages on health care focus on health activities such as appointment reminders, but a growing number deliver health-behavior change messages. A recent review found positive health benefits from SMS-delivered messages targeting diabetes self-management and smoking cessation [65]. Thus far, only college students have been the focus of text-message studies targeting alcohol use [66]. However, with individuals aged 30-49 sending or receiving an average 27 of messages per day, textmessage interventions should be considered as a potential low-intensity intervention targeting adult alcohol use. In addition to sending alcohol-related health messages, an online text system could record drinking goals, ask users how well such goals are being met, and direct those not meeting drinking goals to websites providing treatment and mutual-help resources.

\section{Conclusion}

Rather than developing new forms of intensive treatments for AUDs when current treatments work reasonably well, more effort should focus on expanding the reach of treatment by developing more accessible interventions and exploring how to integrate them into existing alcohol treatment systems. Low-intensity interventions are flexible and can be tailored to address many of the perceived barriers that hinder individuals with AUDs from obtaining timely help. Substantial evidence indicates that low-intensity interventions can engage individuals who shun current treatment options, reduce problematic alcohol use, and may even motivate individuals who need it to engage in more intensive treatment. Given the existence of effective low- and higher intensity interventions to address AUDs and the low levels of treatment uptake, greater attention needs to be focused on implementation-oriented aspects of stepped-care interventions. Several issues regarding the implementation of stepped-care interventions still need to be addressed by the literature, such as identifying the best structure for stepped-care models, understanding the impact of stepped-care interventions on motivation for changing alcohol use, and comparing the effectiveness of stepped-care models across diverse populations.

\section{Competing interests}

The authors declare that they have no competing interests.

\section{Authors' contributions}

JM and RM collaborated on the conception of the manuscript. JM wrote most of the manuscript with the exception of the Methods section and table that was written by JA. JA carried out all literature reviews for the paper. RM provided editorial feedback. All authors read and approved the final manuscript.

\section{Author details}

${ }^{1}$ Center for Healthcare Evaluation, Health Services Research and Development Service, Department of Veterans Affairs Health Care System and Stanford University School of Medicine, Palo Alto, CA, USA. ${ }^{2}$ Department of Psychology \& Robert Wood Johnson Center for Health Policy, University of New Mexico, Albuquerque, NM, USA.

Received: 9 February 2012 Accepted: 2 December 2012 Published: 11 December 2012

\section{References}

1. Finney JW, Wilbourne PL, Moos RH: Psychosocial treatments for substance use disorders. In A Guide to Treatments that Work. Edited by Nathan PW, Gorman JM. New York: Oxford University Press; 2007:156-166.

2. Moos $\mathrm{RH}, \mathrm{Moos} \mathrm{BH}$ : Rates and predictors of relapse after natural and treated remission from alcohol use disorders. Addiction 2006, 101:212-222.

3. Weisner C, Matzger H, Kaskutas LA: How important is treatment? One year outcomes of treated and untreated alcohol-dependent individuals. Addiction 2003, 90:901-911.

4. Cohen E, Feinn R, Arias A, Kranzler HR: Alcohol treatment utilization: findings from the National Epidemiologic Survey on Alcohol and Related Conditions. Drug Alcohol Depend 2007, 86:214-222.

5. Dawson DA, Grant BF, Stinson FS, Chou PS: Estimating the effect of helpseeking on achieving recovery from alcohol dependence. Addiction 2006, 101:824-834.

6. Hasin DS, Grant BF: AA and other help seeking for alcohol problems: former drinkers in the US general population. J Subst Abuse Treat 1995, 7:281-292.

7. Marlatt GA, Tucker JA, Donovan DM, Vuchinich RE: Help-seeking by substance-abusers: the role of harm reduction and behavioral economic approaches to facilitate treatment entry and retention. In Beyond the therapeutic alliance: keeping the drug dependent individual in treatment: NIDA Research Monograph, 165. Edited by Onken L, Blaine JD, Boren JJ. Rockville, MD: US Department of Health and Human Services; 1997:44-84.

8. Kessler R, Aguilar-Gaxiola S, Berglund P, Caraveo-Anduaga J, DeWitt D, Greenfield $S$, et al: Patterns and predictors or preatment seeking after onset of a substance use disorder. Arch Gen Psychiatry 2001, 58:1065-1071.

9. Cunningham JA, Sobell LC, Sobell MB, Agrawal S, Toneatto T: Barriers to treatment: why alcohol and drug abusers delay or never seek treatment. Addict Behav 1993, 27:659-674.

10. Tucker JA, Vuchinich RE, Rippens PD: A factor analytic study of influences on patterns of help-seeking among treated and untreated alcohol dependent persons. J Subst Abuse Treat 2004, 26:237-242.

11. Saunders SM, Zygowicz KM, D'Angelo BR: Person-related and treatmentrelated barriers to alcohol treatment. J Substance Abuse 2006, 30:261-270.

12. Grant B: Barriers to alcoholism treatment: reasons for not seeking treatment in a general population sample. J Stud Alcohol 1997, 36:365-371.

13. Wells J, Horwood J, Fergusson D: Reasons why young adults do or do not seek help for alcohol problems. Aust N Z J Psychiatry 2007, 41:1005-1012.

14. van Olphen J, Freudenberg N: Harlem service providers' perceptions of the impact of municipal policies on their clients with substance use problems. J Urban Health 2004, 81:222-231.

15. Fortney JC, Booth BM, Blow FC, Bunn JY: The effects of travel barriers and age on the utilization of alcoholism treatment aftercare. Am J Drug Alcohol Abuse 1995, 21:391-406.

16. Schmitt SK, Phibbs CS, Piette JD: The influence of distance on utilization of outpatient mental health aftercare following inpatient substance abuse treatment. Addict Behav 2003, 28:1183-1192.

17. Substance Abuse and Mental Health Services Administration (SAMHSA): The NSDUH Report-Alcohol Treatment: Need, Utilization, and Barriers. Rockville, MD: SAMHSA; 2009.

18. Drummond C, Coulton S, James D, Godfrey C, Parrott S, Baxter J, Ford S, Lervy B, Rollnick S, Russell I, Peters T: Effectiveness and cost-effectiveness of a stepped-care intervention for alcohol use disorders in primary care: pilot study. Br J Psychiatry 2009, 31:448-456. 
19. Schuckit MA, Anthenelli RA, Bucholz KK, Hesselbrock VM, Tipp JE: The time course of development of alcohol-related problems in men and women. J Stud Alcohol Drugs 1995, 56:218-225

20. Schuckit MA, Daeppen JB, Tipp JE, Hesselbrock M, Bucholz KK: The clinical course of alcohol-related problems in alcohol-dependent and nonalcohol dependent drinking women and men. J Stud Alcohol Drugs 1998, 59:581-590.

21. Simpson CA, Tucker JA: Temporal sequencing of alcohol-related problems, problem recognition, and help-seeking episodes. Addict Behav 2002, 27:659-674.

22. Babor TF, McRee BG, Kassebaum PA, Grimaldi PL, Ahmed K, Bray J: Screening Brief Intervention, and Referral to Treatment (SBIRT): toward a public health approach to the management of substance abuse. Subst Abus 2007, 28:7-30.

23. Moyer A, Finney JW, Swearingen CE, Vergun P: Brief interventions for alcohol problems: a meta-analytic review of controlled investigations in treatment-seeking and non-treatment-seeking populations. Addiction 2002, 97:279-292.

24. Saitz R, Naimi TS: Adolescent alcohol use and violence: are brief interventions the answer? JAMA 2010, 304:575-577.

25. McCormick KA, Cochran NE, Back AL, Merrill JO, Williams EC, Bradley KA: How primary care providers talk to patients about alcohol: a qualitative study. J Gen Int Med 2006, 21:996-972.

26. Babor TF, Higgins C, Biddle JC, Saunders JB, Monteiro MG: The Alcohol Use Disorders Identification Test: Guidelines for Use in Primary Care. 2nd edition. Geneva: World Health Organization (WHO); 2001.

27. Bohnert AS, Roeder K, Ilgen MA: Unintentional overdose and suicide among substance users: a review of overlap and risk factors. Drug Alcohol Depend 2010, 110:183-192.

28. Khadjesari Z, Murray W, Hewitt C, Hartley S, Godfrey C: Can stand-alone computer-based interventions reduce alcohol consumption? A systematic review. Addiction 2010, 106:267-282.

29. Bamford Z, Booth PG, McGuire J, Salmon P: Minimal intervention as a preparation for the treatment of alcohol dependency. Br J Clin Psychol 2005, 44:289-294.

30. Boon B, Risselada A, Huiberts A, Riper H, Smit F: Curbing alcohol use in male adults through computer generated personalized advice: randomized controlled trial. J Med Internet Res 2011, 13:e43.

31. Brown RL, Saunders LA, Bobula JA, Mundt MP, Koch PE: Randomizedcontrolled trial of a telephone and mail intervention for alcohol use disorders: three-month drinking outcomes. Alcohol Clin Exp Res 2007, 31:1372-1379.

32. Neumann T, Neuner B, Weiss-Gerlach E, Tonnesen H, Dentilello LM, Wernecke $\mathrm{KD}$, et al: The effect of computerized tailored brief advice on at-risk drinking in subcritically injured trauma patients. J Trauma 2006, 61:80-88.

33. Lipsey MW, Wilson DB: Toolkit for practical meta-analysis. Cambridge, MA: Human Services Research Institute; 1996.

34. Apodaca TR, Miller WR: A meta-analysis of the effectiveness of bibliotherapy for alcohol problems. J Clin Psychol 2003, 59:289-304.

35. Sobell LC, Sobell MB, Leo Gl, Agrawal S, Johnson-Young L, Cunningham JA Promoting self-change with alcohol abusers: A community-level mail intervention based on natural recovery studies. Alcohol Clin Exper Res 2002, 26:936-948

36. Cunningham J, Koski-Jännes A, Wild T, Cordingley J: Treating alcohol problems with self-help materials: a population study. J Stud Alcohol 2002, 63:649-654.

37. Sanchez-Craig M: Drink Wise: How to Quit Drinking or Cut Down. 2nd edition. Toronto, Canada: Addiction Research Foundation; 1996.

38. Sanchez-Craig M, Davila R, Cooper G: A self-help approach for high-risk drinking: effect of an initial assessment. J Cons Clin Psychol 1996, 64:694-700.

39. Wild TC, Cunningham JA, Roberts AB: Controlled study of brief personalized assessment-feedback for drinkers interested in self-help. Addiction 2007, 102:241-250

40. Kavanagh D, Connolly JM: Mailed treatment to augment primary care for alcohol disorders: a randomised controlled trial. Drug Alcohol Rev 2009, 28:73-80.

41. McKay JR, Carise D, Dennis ML, Dupont R, Humphreys K, Kemp J, et al: Extending the benefits of addiction treatment: practical strategies for continuing care and recovery. J Sub Abuse Treat 2009, 36:127-130.

42. Mello MJ, Longabaugh R, Baird J, Nirenberg T, Woolard R: DIAL: a telephone brief intervention for high-risk alcohol use with injured emergency department patients. Ann Emerg Med 2008, 51:755-764.
43. Hester R, Squires R, Delaney H: The Drinker's Check-up: 12-month outcomes of a controlled clinical trial of a stand-alone software program for problem drinkers. J Subst Abuse Treat 2005, 28:159-169.

44. Bien T, Miller W, Tonigan J: Brief intervention for alcohol problems: a review. Addiction 1993, 88:315-335.

45. Cunningham J, Wild T, Cordingley J, van Mierlo T, Humphreys K: A randomized controlled trial of an Internet-based intervention for alcohol abusers. Addiction 2009, 104:2023-2032.

46. Pemberton M, Williams J, Herman-Stahl M, Calvin SL, Bradshaw M, Bray R, et al: Evaluation of two web-based alcohol interventions in the US military. J Stud Alcohol Drugs 2011, 72:480-489.

47. Riper H, Kramer J, Smit F, Conijn B, Schippers G, Cuijpers P: Web-based selfhelp for problem drinkers: a pragmatic randomized trial. Addiction 2007, 103:218-227.

48. Postel M, De Haan H, De Jong C: Evaluation of an e-therapy program for problem drinkers: a pilot study. Subst Use Misuse 2010, 45:2059-2075.

49. Blankers M, Koeter MW, Schippers GM: Internet therapy versus Internet self-help versus no treatment for problematic alcohol use: a randomized controlled trial. J Consult Clin Psychol 2011, 79:330-341.

50. Wallace P, Murray E, McCambridge J, Khadjesari Z, White IR, Thompson SG: On-line randomized controlled trial of an Internet based psychologically enhanced intervention for people with hazardous alcohol consumption. PLOS One 2011, 6:1-8.

51. Kramer J, Riper H, Lemmers L, Conijn B, van Straten A, Smit F: Television-supported self-help for problem drinkers: a randomized pragmatic trial. Addict Behav 2009, 34:451-457.

52. Prochaska JO, Velicer WF: Integrating population smoking cessation policies and programs. Public Health Rep 2004, 119:244-252.

53. Monahan SC, Finney JW: Explaining abstinence rates following treatment for alcohol abuse: a quantitative synthesis of patient, research design and treatment effects. Addiction 1996, 91:787-805.

54. Saitz R, Helmuth ED, Aromaa SE, Guard A, Belanger M, Rosenbloom DL: Web-based screening and brief intervention for the spectrum of alcohol problems. Prev Med 2004, 39:969-975.

55. Substance Abuse and Mental Health Services Administration (SAMHSA): Treatment Locator. http://findtreatment.samhsa.gov/ 2011.

56. Alcoholics Anonymous. www.aa.org.

57. Smart Recovery. www.smartrecovery.org

58. Life Ring. www.lifering.org.

59. Lichtenstein E, Zhu SH, Tedeschi GJ: Smoking cessation quitlines: an underrecognized intervention success story. Am Psychol 2010, 65:252-261.

60. Stead LF, Perera R, Lancaster T: A systematic review of interventions for smokers who contact quitlines. Tob Control 2007, 16:S3-S8.

61. Morgenstern J, McKay J: Rethinking the paradigms that inform behavioral treatment research for substance use disorders. Addiction 2007, 102:1377-1389.

62. Lau AS: Making the case for selective and directed cultural adaptations of evidence-based treatments: examples from parent training. Clin Psychol Sci Pract 2006, 13:295-310

63. Shin HB, Kominski RA: Language use in the United States, 2007: American Community Survey Reports, ACS-12. Washington, DC: US Census Bureau; 2010.

64. Pew Research Center Internet and American Life Project: Americans and Text Messaging. Washington, DC: Pew Research Center; 2011.

65. Fjeldsoe BS, Marshall AL, Miller YD: Behavior change interventions delivered by mobile telephone short-message service. Am J Prev Med 2009, 36:165-173.

66. Weitzel JA, Bernhardt JM, Usdan S, Mays D, Glanz K. Using wireless handheld computers and tailored text messaging to reduce negative consequences of drinking alcohol. J Stud Alcohol Drugs 2007, 68:534-543.

doi:10.1186/1940-0640-7-26

Cite this article as: McKellar et al:: Building the first step: a review of low-intensity interventions for stepped care. Addiction Science \& Clinical Practice 2012 7:26. 